\title{
KERYGMAT W MIEŚCIE. RELIGIJNY PERFORMANCE CZY HEIDEGGEROWSKIE WYDARZENIE?
}

20 października 2013 r. papież Franciszek w Orędziu na Światowy Dzień Misyjny zwrócił się do katolików z zachętą do wyjścia zza zamkniętych drzwi kościołów, salek katechetycznych i kapliczek na ulice, by zanieść słowo Boże na „peryferie”, zwłaszcza tym, którzy nie mieli jeszcze możliwości poznania Chrystusa. Podkreślając misyjny charakter Kościoła, papież posłużył się kategorią peryferii nie w znaczeniu terytorialnym, przestrzennym, ale przede wszystkim etycznym: „Wymiana zawodowa i kulturowa, za którymi postępują turystyka i zjawiska jej podobne, powodują wielkie migracje ludzi. Niekiedy nawet wspólnotom parafialnym trudno jest stwierdzić $\mathrm{z}$ całą pewnością, które osoby przebywają czasowo, a które mieszkają na stałe na terytorium ich parafii. Ponadto na obszarach, które od zawsze były regionami tradycyjnie chrześcijańskimi, wzrasta liczba tych, dla których wiara jest obca, są obojętni religijnie albo mają inne wierzenia. Zresztą nie jest rzadkością, że niektórzy ochrzczeni dokonują takich życiowych wyborów, które oddalają ich od wiary, co sprawia, że potrzebują „,nowej ewangelizacji”. Do tego wszystkiego dochodzi fakt, że do ogromnej części ludzkości nie dotarła jeszcze Dobra Nowina Jezusa Chrystusa".

W wypowiedzi tej widoczne wydaje się inne niż europejskie rozumienie przestrzeni scentralizowanej, wyrażonej przez ideę miasta

Orędzie papieża Franciszka na Światowy Dzień Misyjny 2013 r. Tekst przemówienia na: https:/w2.vatican.va/content/francesco/pl/messages/missions/ documents/papa-francesco_20130519_giornata-missionaria2013.html (dostęp: $10 \times 2015)$. 
zbudowanego wokół kulturowej axis mundi. Za tymi słowami stoi doświadczenie południowoamerykańskich metropologii z licznymi favellas rozlokowanymi wokół ,jądra" ekonomicznego i kulturowego miasta. Jednocześnie warto zwrócić uwagę na teologiczny trop wypowiedzi Ojca Świętego - franciszkańskie źródła idei Kościoła ubogich, reprezentowanej w XX w. przez Karola de Foucaulda, do którego niejednokrotnie odwoływał się papież z „,końca świata”.

\section{Odnowa Kościoła przychodzi przez ubogich ${ }^{3}$}

Wezwanie misyjne papieża Franciszka koresponduje w bardzo wyraźny sposób ze zjawiskiem nowej ewangelizacji, z duchem II Soboru Watykańskiego, który w konstytucji dogmatycznej Lumen gentium ukazuje rolę Kościoła jako światła dla narodów. Jednak by mógł on spełnić swoją powinność, potrzebny jest ktoś, kto zaniesie owo światło tam, gdzie panuje mrok. W takiej roli odnajduje się jedna z rzeczywistości posoborowych - Droga Neokatechumenalna, która powstała na przedmieściach Madrytu w latach 60. ubiegłego stulecia.

Narodziny Drogi związane są z historią dwojga inicjatorów: Kiko Argüello i Carmen Hernandez. Kiko, niezwykle obiecujący artysta, zdobywający uznanie w świecie malarskim, po przejściu głębokiego kryzysu egzystencjalnego, zafascynowany postacią wspomnianego już Karola de Foucaulda postanawia zamieszkać w Palomeras Altas, na przedmieściach Madrytu. Dzielnicę baraków zamieszkiwali społecznie odrzuceni: „Cyganie, «żuleria» zwana w Hiszpanii quiniquis: włóczędzy, kloszardzi, żebracy, stare prostytutki..., okropne miejsce". ${ }^{4}$ Mając ze sobą jedynie Biblię i gitarę rozpoczyna życie $\mathrm{z}$ ubogimi, mieszkając $\mathrm{w}$ baraku bez ogrzewania, otoczony psami, by

2 L. Ś liw a, Franciszek. Papież z końca świata. Biografia, Kraków 2013, s. 29-71.

3 Słowa: „O d n ow a K oś c i oła, jeśli pr z y j z i e, to przez charyzmaty u b o g i c h świeckich" zostały wypowiedziane przez papieża Jana XXIII w przemówieniu przygotowującym do Vaticanum II, wygłoszonym 11 IX 1962 r.

4 K. A rg ü e 11 o, Kerygmat z ubogimi w barakach. Doświadczenie Nowej Ewangelizacji: missio ad gentes, Lublin 2013, s. 38. 
grzać się ich ciałami w zimie, staje się znakiem zapytania dla tych, którzy zostali skazani na peryferia. Daje lekcje rysunku okolicznym mieszkańcom, z tego się utrzymuje, modli się i gra na gitarze, czym zjednuje sobie najpierw Cyganów a potem pozostałych. W tym czasie do Palomeras przyjeżdża Carmen Hernandez, z wykształcenia chemiczka, kobieta, której celem jest przygotowanie wyprawy misyjnej do Boliwii. Próbując zebrać ekipę ewangelizatorów, trafia do baraków, by namówić Kiko Argüello do wyjazdu, jednak to, co zobaczyła na miejscu, przerosło jej oczekiwania. Zafascynowana tym dziełem ewangelizacyjnym zamieszkuje w barakach i towarzyszy misji Kiko, wprowadzając w to wydarzenie ducha soborowego. W ten sposób powstał zrąb życia katechumenalnego: „Robiliśmy celebrację Słowa z Cyganami, raz w tygodniu, i ci biedacy zmuszali mnie, żebym im mówił o Chrystusie. Stopniowo pojawiła się wspólnota chrześcijańska, wspólnota ubogich - to byli Cyganie, jakaś kobieta, która się prostytuowała, jakiś stary kloszard, który zbierał tekturę i żył jak ludzki śmieć (...). Czasami odprawialiśmy Eucharystię. Między ubogimi zaczęło coś powstawać. Narodziło się to, co dzisiaj na Drodze nazywamy trójnogiem: Słowo, Eucharystia i wspólnota chrześcijańska". ${ }^{5}$

W ten sposób rozpoczyna się historia wspólnot, które obecnie są rozsiane na całym świecie i w swoim charyzmacie mają wpisaną ewangelizację rozumianą jako misja do pogan. Wyraża się ona w konkretnych zjawiskach, które inicjatorzy Drogi Neokatechumenalnej nazwali misio ad gentes oraz comunitaties in missionem. Pierwsza z form ewangelizacji polega na wysyłaniu kilku wielodzietnych rodzin wraz z prezbiterem (ok. 50 osób) do tych krajów i diecezji, w których działalność Kościoła już zamarła lub nigdy jej nie było (np. Chiny). Owe rodziny zaczynają żyć w sposób chrześcijański, stając się świadectwem dla pogan. Na całym świecie działa obecnie ponad 100 takich misji, co roku papież Franciszek, wzorem swoich poprzedników (pierwsze misje wysyłał Jan Paweł II), w styczniu wysyła kolejne rodziny. Druga forma - comunitaties in missionem - ma

\footnotetext{
5 Tamże, s. 57.
} 
charakter bardziej lokalny i dotyczy wspólnot neokatechumenalnych, które skończyły całą formację. Na zaproszenie biskupa miejsca przenoszone są one do parafii (innych miast czy nawet innych diecezji), by odnawiać tam życie chrześcijańskie oparte na rytmie: celebracja Słowa, uczestniczenie w liturgii eucharystycznej i wspólne dzielenie się wszystkim.

Te dwie formy ewangelizacji pokazują, że charyzmatem Drogi jest zarówno ewangelizacja, głoszenie kerygmatu - Dobrej Nowiny o miłości Boga do człowieka, oparte na doświadczeniu życia oraz skierowanie się ku ubogim, odrzuconym, tym, którzy pozostają na peryferiach.

\section{Misja na 100 placach}

Z misyjnego charakteru Drogi papież Franciszek korzystał w Buenos Aires jeszcze jako kardynał Jorge Bergolio, nic zatem dziwnego, że po objęciu Stolicy Piotrowej, skierował wiosną 2013 r. zaproszenie do inicjatorów Drogi Neokatechumentalnej - Kiko Argüello, Carmen Hernandez i o. Mario Pezzi do dzielenia się Ewangelią na „100 placach Rzymu”. Początkowo inicjatywa Ojca Świętego była pomyślana lokalnie, jako dziękczynienie za 40 lat Drogi w Rzymie (jubileusz ten w 2012 r. świętowała parafia Męczenników Kanadyjskich, w której 40 lat wcześniej odbyły się pierwsze katechezy neokatechumenalne), tymczasem na wezwanie inicjatorów Drogi swoją misję ewangelizacyjną przygotowała większość wspólnot na całym świecie. Słowo Boże było głoszone w 10 tys. miejsc - na placach, w parkach, przed kościołami czy supermarketami. Wstępna statystyka mówi, że do Kościoła zbliżyło się wówczas ok. 40 tys. ludzi, czy to przez sakrament nawrócenia, czy przyjęcia chrztu. Dla niektórych było to pierwsze spotkanie z Chrystusem. Zdarzały się też spektakularne nawrócenia - osób bez nadziei, które myślały o samobójstwie, którym to uliczne wyjście z Ewangelią na peryferia uratowało życie.

Od pierwszej misji na placach minęły trzy lata, w czasie których trzykrotnie wspólnoty neokatechumenalne wychodziły „na 
peryferia" z Ewangelią Jezusa Chrystusa. Misje co roku odbywają się zawsze w czasie paschalnym: od Niedzieli Miłosierdzia do Niedzieli Wniebowstąpienia, w niedzielne popołudnia między godziną 15.00 a 18.00 na placach, rynkach lub w innych znaczących miejscach komunikacyjnych miasta. Ich przebieg opiera się na kilku stałych elementach: śpiewach, liturgii nieszporów, świadectwach braci, którzy doświadczyli działania Boga w swoim życiu oraz katechezie. Pięć kolejnych spotkań ma swoją ustaloną tematykę, skupioną wo-
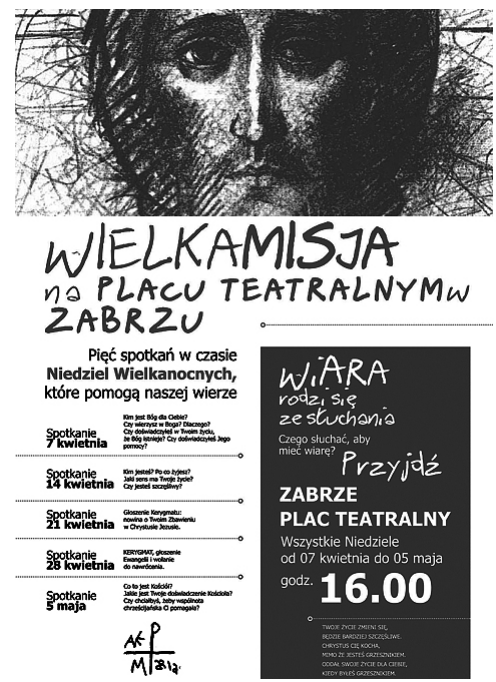

Fot. 1 kół kerygmatu. ${ }^{6}$ Pierwsza katecheza zadaje pytanie o miejsce Boga w życiu, zderzając potoczne wyobrażenia z doświadczeniem Boga żywego: Boga Abrahama, Mojżesza i św. Pawła. Kolejna pyta o sens życia, ukazując egzystencję ludzką w kontekście doświadczenia antropologicznego - życia codziennego, które wydaje się niewystarczające. Trzecia i czwarta katecheza głoszą kerygmat, ostatnia zaś skupia

6 Pojęcie „kerygmat”, pochodzące z języka greckiego i oznaczające „głoszenie”, „wezwanie”, „proklamację” zostało przez Kościół pierwszych wieków jednoznacznie związane z Dobrą Nowiną o Jezusie Chrystusie. Lektura Dziejów Apostolskich przynosi kilka kerygmatów począwszy od pierwszego wyznania św. Piotra w dzień Pięćdziesiątnicy a skończywszy na kerygmatycznych obwieszczeniach św. Pawła. Pierwotny kerygmat apostolski zawierał cztery elementy: obietnicę, krzyż, zmartwychwstanie i dar Ducha Świętego. Głoszenie kerygmatu sprowadza się do wołania, krzyku, ogłaszania orędzia, ale, co także ważne, do dawania świadectwa. Jak zauważa bp Grzegorz Ryś: , Jeśli głosisz kerygmat, musisz dać świadectwo. Jak nie dajesz świadectwa, nie głosisz kerygmatu"; G. R y ś, Dzieci królestwa, Bytom 2014, s. 130. Więcej na temat kerygmatu pierwotnego i jego funkcji w Kościele zob. R. P i s u la, Kerygmat apostolski dzisiaj. Biblijno-teologiczna synteza dla nowej ewangelizacji, Lublin 2005. 


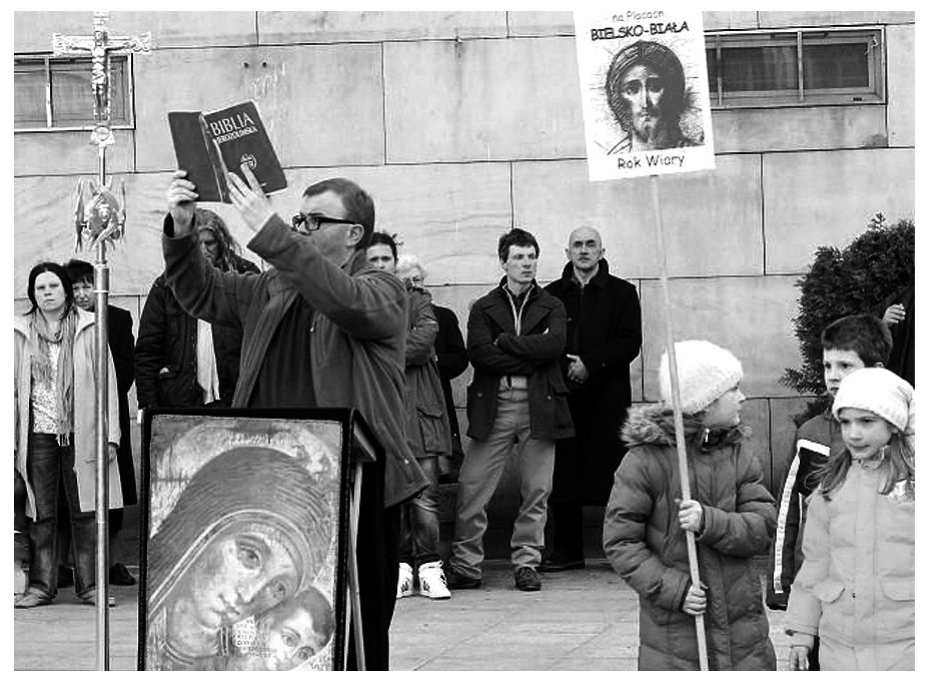

Fot. 2

się na włączeniu tej Dobrej Nowiny przez życia chrześcijańskie, której najpełniej realizuje się w Kościele (fot. 1).

Każdą z niedzielnych misji rozpoczyna zgromadzenie, czyli zebranie się przedstawicieli wspólnoty, którzy mają być pierwszym widocznym znakiem wydarzenia, za pomocą którego dokonuje się ewangelizacja. Zgromadzenie chrześcijan, którzy „żyją w jedności i miłości”, radując się ze zmartwychwstania, ma wskazywać na źródło Dziejów Apostolskich, kiedy po zesłaniu Ducha Świętego apostołowie wychodzącą z Wieczernika i „krzyczą z radości” (Dz 2). W konstruowaniu zgromadzenia pomagają inne znaki, odwołujące się do liturgii kościelnych: ambona z welonem, krzyż, dywan usytuowany w środku zgromadzenia. Budowana w ten sposób przestrzeń nawiązuje do metafory Kościoła jako ciała Chrystusa, w które zgromadzeni są jego członkami (por. 1 Kor, Rz, Ef). Celebrację rozpoczynają śpiewy, którym towarzyszy taniec całego zgromadzenia, chętnie 
włączającego przypadkowych przechodniów. ${ }^{7}$ Następnie rozpoczyna się liturgia nieszporów niedzielnych, którym przewodniczy ksiądz ubrany w szaty liturgiczne, a między czytanymi lub śpiewanymi psalmami dawane są świadectwa członków wspólnoty o osobistym doświadczeniu Boga. Po responsorium prezbiter otwiera Ewangelię a caso i przepowiada słowo, które jest proroctwem dla tego miasta i jego mieszkańców. Po tym następuje wspomniana katecheza (fot. 2). Warto w tym miejscu podkreślić, że w głoszeniu kerygmatu najważniejszy jest fakt przepowiadania, które nie jest nastawione na sukces ani na poklask. Po katechezie czyta się modlitwę powszechną i śpiewa Magnificat, a następnie tańczy i śpiewa inne pieśni, zapraszając na kolejne spotkania na placu.

\section{Przestrzeń kerygmatu}

Koncepcja misji na „100 placach” koresponduje dość mocno z wezwaniem do ewangelizacji „na peryferiach”, gdyż zazwyczaj centralnie ulokowane przestrzenie zostały pozbawione całkowicie religijnego aspektu komunikacyjnego, choć niejednokrotnie wypełnione są śladami po chrześcijańskiej tradycji w postaci pomników wotywnych, kościołów czy kaplic pełniących dziś przede wszystkim funkcję atrakcji turystycznej czy muzeum. Jeszcze inaczej ową przestrzeń centralną można rozumieć w przypadku przesunięcia jej ze względów ekonomicznych ku centrom handlowym. Okazuje się zatem, że owe chrześcijańskie peryferia znajdują się w samym centrum wielkomiejskiej przestrzeni.

W kulturoznawczej refleksji nad przestrzenią od dawna panuje przekonanie, że przestrzenie otrzymują swoją istotę od miejsc rozumianych antropologicznie. Oznacza to, że sens danego miejsca, realnego lub wyobrażonego, wyznacza bardziej abstrakcyjne pojęcie przestrzeni, a nie odwrotnie. W przypadku miejsc głoszenia

7 Taniec wspólnotowy w kole nawiązuje do tradycji hebrajskiej, tańca Jakuba, podkreślając jego ułomność i wspieranie się na drugim, składa się czterech kroków powtarzanych przez wszystkich w tym samym tempie i rytmie. 


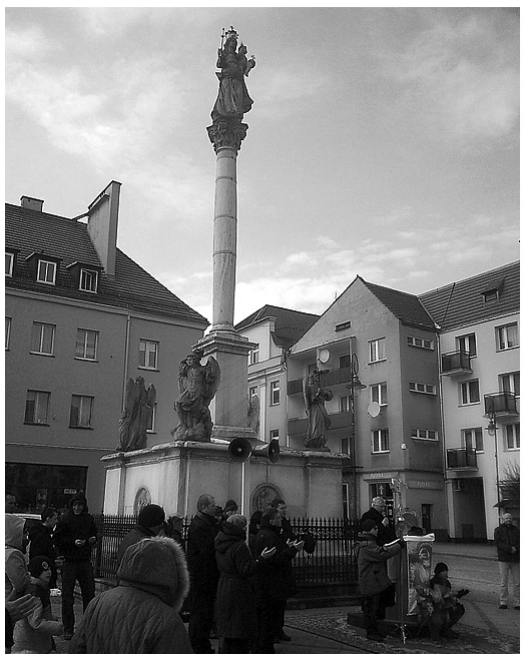

Fot. 3

Ewangelii realne miejsce jest raczej czymś wtórnym wobec przestrzeni kerygmatu. Powstaje ona jako efekt dynamicznej relacji między Słowem a człowiekiem, który pod jego wpływem otwiera się na ,drugiego" - nie jest to istotne czy będzie to inny chrześcijanin, współwyznawca czy ktoś religijnie czy kulturowo „obcy”. Dlatego to nie miejsce, ale przestrzeń kerygmatyczna przestrzeń spotkania Chrystusa w drugim człowieku pozwala osadzić w miejscu wydarzenie misyjne. Staje się ono tylko przyczółkiem, punktem zaczepienia, punktem wyjścia, nie zaś miejscem docelowym. Tym pozostaje rzeczywistość transcendentna, miejsce symboliczne, do którego każdy chrześcijanin pielgrzymuje.

Warto jednak zatrzymać się na kategorią miejsc wybieranych na ewangelizację przez Drogę Neokatechumenalną. W samym założeniu, „misja na 100 placach Rzymu” była pomyślana jako wejście z kerygmatem w tzw. miejsca antropologiczne, naznaczone pamięcią, będące wyrazem tożsamości kulturowej, uruchamianej i identyfikowanej przez mieszkańców danego miasta. Miejsca te są przestrzeniami tożsamościowymi, podlegającymi procesom racjonalizowania i rozpoznawalności, wpisanymi na stałe w mentalną mapę przestrzeni miejskiej. Co za tym idzie, mają ono naturę geometryczną, wychodzącą od trzech prostych kategorii przestrzennych. Są to także miejsca, z którymi buduje się relacje, utożsamia z pewnymi wydarzeniami, odnoszącymi się do historii ważnej dla mieszkańców. Miejsca te korespondują z regułami życia społecznego i obyczajowego danego terytorium, którego znaczenia konkretyzują się w czasie teraźniejszym. Ta identyfikacja jest niezwykle ważna 


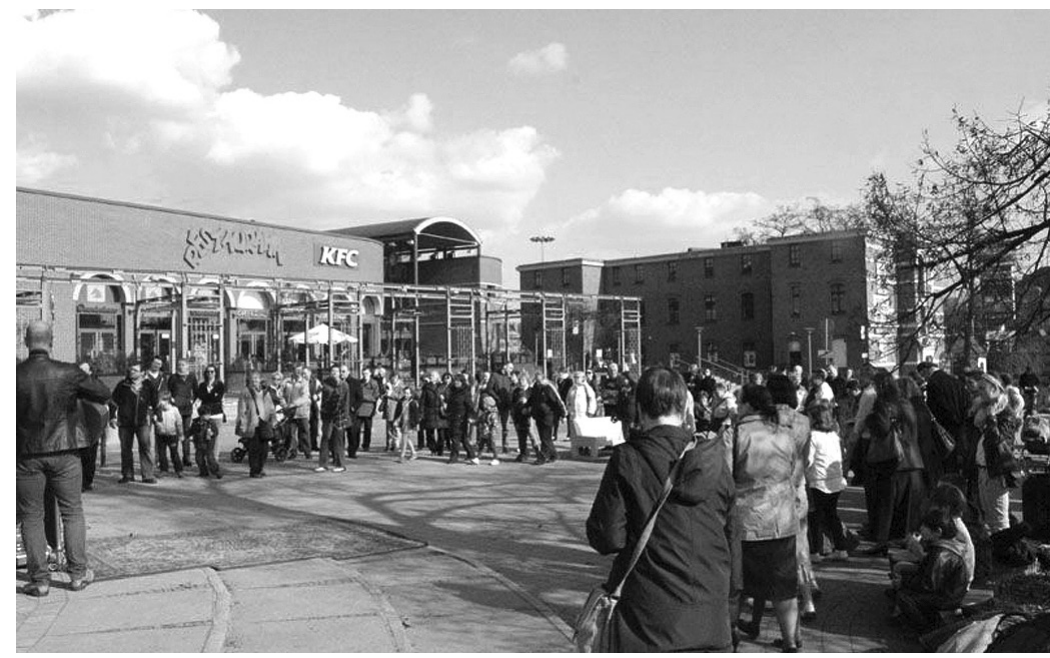

Fot. 4

z perspektywy głoszenia Dobrej Nowiny, dlatego też opisywane misje bardzo często sytuowane są przy różnego rodzaju pomnikach, ratuszach, fontannach i innych znaczących miejscach miasta (fot. 3).

W nieco inne perspektywie rysuje się misja usytuowana w przestrzeni symbolicznie neutralnej, by nie powiedzieć pustej. Mowa tu o różnego rodzaju parkingach przed galeriami handlowymi, placach przed wejściami do centrów rozrywki, przed dworcami, w pasażach $\mathrm{i}$ innych tego typu przestrzeniach anonimowych, wywłaszczonych z granic terytorialnych, pozbawionych więzi społecznych czy wręcz tożsamości (identyfikacji, realności i historyczności czyli tego, co określa się pamięcią symboliczną). Miejsca te trzeba by nazwać, za francuskim antropologiem Markiem Augé, „nie-miejscami”, do których dostęp ma codziennie każdy, nieraz w sposób przypadkowy (fot. 4). A udział w tej przestrzeni nie wymaga od jego użytkownika uruchomienia pamięci ani włączenia określonej narracji.

8 M. A u g é, Nie-miejsca. Wprowadzenie do antropologii hipernowoczesności, tłum. R. C h y m k o w s k i, Warszawa 2010, s. 51-79. 
Z „nie-miejscem” sytuacja „misji na placach” łączy kategoria przestrzeni egzystencjalnej, w której relacja z miejscem oparta jest już nie na symbolicznym znaczeniu miejsca ukonstytuowanego tradycją, ale w sposób indywidualny na zasadzie samotnej umowności. Uczestnik misji doświadcza bowiem spotkania, które staje się podstawowe dla jego egzystencji i kontekstualizuje owo miejsce, wyznaczając je jako punkt odniesienia dla swego życia. Owo miejsce bowiem może być za każdym razem inne (misje na placach często przenoszą się ze względu na pozwolenia służb miejskich), a jednocześnie jest ono tym samym miejscem dla kogoś, kto usłyszał Dobrą Nowinę, która stała się dla niego początkiem nowego życia. Podobnie ważna wydaje się przypadkowość „,nie-miejsca”, która ma swoje przełożenie na sytuowanie miejsca liturgicznego wyznaczanego przez znaki (dywan, ambonę, krzyż, paschał) w przestrzeni całkowicie niesakralnej: przed hipermarketem, fastfoodową restauracją, galerią handlową itp., która z przestrzeni nienazwanej staje się znacząca ze względu na opowieść - moment spotkania, usłyszeniem kerygmatu. W tym sensie można rozumieć wypowiedź Michela de Certeau; „Przestrzeń byłaby dla miejsca tym, czym staje się słowo w chwili, gdy jest wypowiadane, to znaczy pochwycone w niepewności urzeczywistniania, przemienione w określenie będące wynikiem rozmaitych konwencji, rozumiane jako akt jakiejś teraźniejszości albo jakiegoś czasu, oraz zmodyfikowane w wyniku pojawiania się kolejnych układów". 9

W obu przypadkach przestrzeń profanum staje się miejscem świętym - kościołem, nie ze względu na swoją geometrię, architektoniczność (fizyczność - nie ma wszak budynku), ale z powodu znaków, zachowań, gestów o charakterze symbolicznym - jednoznacznie religijnym. Są one wyrażane zarówno przez sam fakt wspólnoty (zgromadzenia), obecność prezbitera w stroju liturgicznym w przestrzeni profanum, jak i przez treść: przepowiadanie Dobrej Nowiny, odprawianie liturgii, śpiewy itd. Produkcja treści symbolicznych

9 M. d e C e r te a u, Wynaleźć codzienność. Sztuki działania, tłum. K. Th i e l- J a ń c z u k, Kraków 2008, s.117. 
przenika warstwę życia codziennego, wchodzi w rym toczącego się „teraz".

\section{„Staliśmy się bowiem widowiskiem światu...” (1Kor 4,9)}

Usytuowanie miejsca przepowiadania słowa Bożego w przestrzeni publicznej nosi znamiona widowiska kulturowego, rozumianego jako zbiór zachowań, w których ,jedna lub więcej osób przejmuje odpowiedzialność za publiczność i za tradycję - tak, jak sami ją pojmują". ${ }^{10}$ Już samo zorganizowanie przestrzeni o charakterze liturgicznym: rozłożenie dywanu na kostce brukowej rynku czy asfalcie, ustawienie ambony, postawienie w centrum krzyża, rozlokowanie w kręgu członków wspólnoty przed wybranym centrum handlowym wyodrębnia tę przestrzeń i nadaje jej znamiona miejsca scenicznego. Już samo zgromadzenie wprowadza obecnych w tym miejscu czy przechodniów w kategorię widowiskowości ze względu na elementy ceremonialności liturgicznej, podejmowaną komunikację interpersonalną w głoszonej katechezie - często dialogowanej z obecnymi tam odbiorcami czy samą kategorię estetyczną, która wyraża się czy to w konstrukcji miejsca liturgicznego na tle świeckiej przestrzeni czy w wykonywaniu śpiewów przy akompaniamencie instrumentów, które mogą zachwycać swoją melodyką czy interpretacją. Niejednokrotnie to właśnie wykonywane pieśni są bodźcem do zatrzymania się, przyjrzenia się niezwykłemu „zjawisku”, a nawet włączenia się w taniec. Zdarza się, że niektórzy uczestnicy widowiska podchodzą po zakończonej ewangelizacji do kantorów i proponują „występ” na jakiejś uroczystości rodzinnej (nierzadko świeckiej), traktując te elementy ewangelizacji jako oprawę muzyczną lub część występu jakiś rodzaj koncertu. Innych porusza dawane świadectwo lub głoszona katecheza, choć bardzo często wypowiedzi te są odbierane

10 J.J. M a c A 1 o o n, Wstęp: widowiska kulturowe, w: t e n ż e (red.), Rytuat, dramat, święto, spektakl. Wstęp do teorii widowiska kulturowego, tłum. K. P r z y Ł u s k a - U r b a n o w i c z, Warszawa 2009, s. 24. 
w kategoriach „występu”, który wzbudził podziw dzięki szczególnym umiejętnościom.

Opisane sytuacje pozwalają, za Zygmuntem Raszewskim, zdefiniować ewangelizację na placach jako widowisko o układzie otwartym, w którym publiczność w każdej chwili może przekształcić się we współuczestników, choć przebieg wydarzenia odbywa się według ustalonych przepisów - schematu, co wskazywało na powinowactwo z rytuałem, który wymaga określonego typu zachowań. Doskonałym przykładem są reakcje ludzi przechodzących przez rynek czy place lub parkingi przed centrami handlowymi, którzy, widząc znaki liturgiczne oraz ubranego w szaty księdza, reagują dwojako. Jedni z przyzwyczajenia przyklękają, robią znak krzyża, wpisując się w narzuconą przez rytuał formę, inni - mając świadomość znaczeń wyrzekają, że miejsce na „takie rzeczy” są w kościele (w znaczeniu świątyni). Co ciekawe, oba typy zachowań są charakterystyczne dla ludzi deklarujących się jako katolicy. Publiczność areligijna traktuje uliczną ewangelizację z większym dystansem, uznając ją właśnie za rodzaj przedstawienia, wydarzenia kulturalnego czy jak opisywał to św. Paweł - „widowisko światu”, w który wpisana jest zarówno kategoria teatralności jak i pewnej śmieszności, niestosowności. Znamienne wydają się postawy odbiorców przystających przy zgromadzeniu ewangelicznym, którzy uczestniczą przez chwilę w wybranym (interesującym dla siebie) fragmencie tego wydarzenia, komentujący takie czy inne wykonanie, przypatrujący się tańcom itp. Wspomnianą w kontekście głoszenia kerygmatu przez Pawła sytuację „głupstwa dla świata" dobrze oddaje niemal każdorazowa obecność osób pijanych oraz chorych umysłowo, którzy jako pierwsi uczestnicy tego wydarzenia włączają się bez żadnych zahamowań w jego przebieg. Brak społecznych ograniczeń wynikający z rozluźnienia więzów ograniczeń umysłowych czy woluntarnych powoduje dość chętne włączanie się takich osób w taniec, śpiewy, odpowiadanie na pytania katechistów. Co więcej, to oni zdają się być beneficjentami tego przepowiadania, a z drugiej strony ich obecność potwierdza przekonanie większości uczestników widowiska, że to, co dzieje się w na placu, jest czystym szaleństwem, jakimś rodzajem commedii dell'arte. 


\section{„W dobrych zawodach wystąpilem...” (2Tm 4,7)}

Jeśli omawiane wydarzenie ewangelizacyjne pozwala się zdefiniować w kategoriach teatralnego widowiska, to jedynie wówczas, gdy patrzy się na nie wyłącznie z perspektywy rytualności czy ceremonialności przebiegu zdarzenia. Warto jednak zauważyć, że celem ewangelizacji i głoszenia kerygmatu nie jest „występ” rozumiany jako odegranie przedstawienia czy ukazanie roli, ale przepowiadanie „Dobrej Nowiny”, które dokonuje się publicznie, „twarzą w twarz”. W głoszenie kerygmatu wpisane jest zatem takie działanie, które ma na celu wywarcie określonego wrażenia, ze względu na bezpośredniość interakcji i prawdziwość. Tym samym złamana zostaje kategoria sztuczności spektaklu ewangelizacyjnego, wynikająca z sytuacji teatralnej, na rzecz autentyczności. W ulicznej ewangelizacji wraża się to chociażby przez identyfikację: prowadzący, katechista czy dający świadectwo przedstawiają się na początku, mówią zawsze o sobie, o własnym doświadczeniu.

Napięcie między formą „występu” a prawdziwością opisuje Erving Goffman, który, analizując sposób bycia jednostki w świecie, podobnie jak Gombrowicz zauważa, że w życiu codziennym człowiek w kontakcie $\mathrm{z}$ drugim wytwarza i podtrzymuje jakiś wizerunek siebie. Owo konstruowane kulturowo ,ja” może być bliskie osobowości, ale może też stawać się postacią sceniczną ze względu na pełnioną publicznie rolę. Odnosząc się do tej metafory Goffmana przestrzeni życia codziennego jako teatru, można odnieść ją do omawianej sytuacji „występu ewangelizacyjnego" ze względu na jej publiczny charakter, wymagający wejścia $\mathrm{w}$ rolę. ${ }^{11}$

Nie da się ukryć, że konstruowane przez wspólnotę miejsce liturgiczne można potraktować jako swoistą scenografię, którą Goffman definiuje jako fasadę. Rozłożony dywan, ustawiony centralnie krzyż, postawiona na czele zgromadzenia ambona nie tylko zarysowują kształt przestrzeni, ale także dostarczają informacji o charakterze

${ }^{11}$ E. G o f f m a n, Człowiek $w$ teatrze życia codziennego, tłum. H. D a t n e r - Ś p i e w a k, P. Ś p i e w a k, Warszawa 2000, s. 53-59. 
przedstawienia. Co ciekawe, dekoracja jest mobilna, bowiem ustawiana jest przed samym wydarzeniem i usuwana zaraz po nim, sama czynność zaś jest powtarzalna. Do elementów definiujących sytuację należą także rekwizyty wykorzystywane przez prowadzących podczas przedstawienia: krzyż przy wygłaszaniu kerygmatu lub czaszka przy katechezie o sensie życia, podobne znaczenie otrzymują instrumenty w rękach kantorów wykonujących pieśni. Specyficznym rodzajem identyfikacji jest fasada osobista, na którą składają się osobiste środki wyrazu związane z samym wykonawcą jak płeć, wygląd fizyczny, sposób wyrażania (intonacja, mimika, gest), ale także strój, pozycja społeczna itd. Częściami tej fasady mogą być także pewne znaki (insygnia) określające rolę postaci w wydarzeniu. $\mathrm{W}$ ewangelizacji elementy fasady najbardziej widoczne są w postaci prezbitera: ubranego w strój liturgiczny (sutannę, albę), mającego insygnia związane z pozycją (stuła na albie) i urzędem apostolskim (odczytującego Ewangelię, udzielającego rozgrzeszenia, błogosławieństwa), ale i w innych osobach występu: katechistach czy dających świadectwo, których sposób mówienia (ton głosu, intonacja, silniejsze podkreślanie pewnych fraz) określa pozycję i znaczenie udziału w wydarzeniu. Opisywana tu „fasada osobista” jest zawsze ruchoma, zawsze gotowa, by udać się wraz z aktorem, unieważniając linię podziału między widownią a sceną. ${ }^{12}$

12 Pomijam w tym miejscu opisywana przez Goffmana kategorię sceniczności w sytuacjach życia codziennego, w których daje się wydzielić scenę i kulisy. W opisywanym tu wydarzeniu ewangelizacyjnym już sam układ zgromadzenia ma charakter sceniczny ze względu na miejsce przewodniczenia - ambonę, z której czytane są teksty liturgiczne, wygłaszana katecheza, odczytywana Ewangelia, dawane są świadectwa itd. Natomiast kulisy przybierają kształt metaforyczny, nie ma bowiem miejsca osobnego w ewangelizacji ulicznej, co jeszcze bardziej podkreśla kategorię autentyczności wydarzenia. Granica jest między sceną a kulisami, podobnie jako między sceną a widownią, jest mentalna. Kulisy pozostają nieco z boku lub tyłu sceny, gdzie poprawia się strój liturgiczny, przygotowuje kolejne pieśni do śpiewania, wyznacza role kantorów, określa kolejność dawania świadectwa itd. 
Do zabiegów teatralizacyjnych Goffman zalicza także dramatyzację działania, która polega na silnej emocjonalizacji wydarzenia. W trakcie interakcji podkreśla się znacząco sposób wyrażania, zwracając uwagę na istotę przekazu - kerygmatu. Taki właściwościami z pewnością wykazują się wszelkiego rodzaj świadectwa osób, publicznie dzielących się doświadczeniami swojego życia, często naznaczonych olbrzymimi cierpieniami, w które wkraczał Bóg ze swoim działaniem. Niejednokrotnie podczas świadectw wypowiadająca je osoba wzruszała się, łkała, czasem milkła, przerywając gwałtownie wypowiedź. Trudno uznać owe zachowanie za przejaw teatralności, wręcz przeciwnie, świadczą one o autentyczności, aczkolwiek noszą znamiona zachowań scenicznych, przesadnie wręcz afektywnych. Nieco inaczej należy spojrzeć na dramatyzację wypowiedzi katechistów, którzy budują swoją wypowiedź na dostępnych sobie środkach ekspresji, wykorzystując wspomniane już elementy ,fasady osobistej" (ton głosu, intonację), a także posiłkując się pewnymi chwytami oratorskimi: kumulowaniem pytań retorycznych, elipsami, chwilami milczenia, silnie obrazowymi przykładami itp. Wobec powyższego trudno uciec od skojarzenia z teatralnością wypowiedzi, choć - jak pokazuje praktyka - sama forma nie trafia do odbiorców. Bardzo często wobec pokusy szafowania teatralnymi gestami podczas ulicznej ewangelizacji przypomina się scenę przemowy św. Pawła na Areopagu do Greków (Dz 17, 22-33), który, mając do dyspozycji cały wachlarz środków i olbrzymią wiedzę wynikającą ze swego wielokulturowego wykształcenia i obycia, ponosi ewangelizacyjną klęskę. Zatem nie o środki ekspresji tu chodzi, lecz o Ducha, który stoi za przepowiadającym kerygmat. Do jeszcze innej kategorii dramatycznej należą śpiewy i tańce, które mają zwrócić uwagę przechodzących: zainteresować, przykuć uwagę, a nawet włączyć w krąg tańczących. Ten dynamiczny element ewangelizacji jest niezwykle istotny, gdyż poza widowiskowym charakterem, niesie on ze sobą znaczenia: młodości, radości, witalności. Rodzi u przechodniów pytanie: „Skąd oni to mają?”, „Z czego się radują?”, „Czy upili się młodym winem?" (por. Dz 2,13). 
Tym samym, idąc tropem Goffmana, można wydarzenie ewangelizacyjne zdefiniować jako performance, zwracając uwagę, że jego najważniejszym punktem odniesienia jest uczestnik interakcji, którego rola nie sprowadza się tylko do zajęcia miejsca na widowni, ale jest on zaproszony do współuczestniczeniu w tymże wydarzeniu. Bowiem performance w przeciwieństwie do widowiskowości i przedstawienia koncentruje się nie tylko na efektach, ale raczej na przyczynach ich podjęcia i sposobie przeprowadzenia. ${ }^{13}$ Nie można bowiem zarzucić wspólnotom ewangelizującym, że ich celem jest „łowienie” nowych członków Kościoła, nie liczy się tak rozumiany efekt, ale samo działanie - głoszenie kerygmatu, do którego wzywa osobiste doświadczenia miłości Boga wyrażone słowami św. Pawła „Caritas Christi urget nos ...” (2Kor 5,14).

$\mathrm{Z}$ tej perspektywy ciekawie wygląda propozycja funkcji performance, które wylicza Richard Schechner. ${ }^{14}$ Przyglądając się różnym źródłom i ich sposobom realizacji, przedstawia on siedem propozycji. Performance realizuje się by: zabawiać, tworzyć coś pięknego, ustanawiać lub zmieniać tożsamość, budować lub podtrzymywać wspólnotę, uzdrawiać, nauczać czy przekonywać, oraz obcować z tym, co święte. Ta ostatnia funkcja w kontekście omawianego wydarzenia ewangelicznego wydaje się oczywista. Wychodzenie z kerygmatem na „peryferia” miasta pozwala doświadczyć tego, co święte w życiu już całkowicie zeświecczonym, sprofanowanym. Zresztą taka intencja od początku przyświecała wezwaniu do ewangelizacji papieża Franciszka. Ze względu na charakter wydarzenia i centralne umiejscowienie w nim kerygmatu, można także rozumieć znaczenie funkcji dydaktycznej. Kerygmat, w którego istocie ukrywa się ekspresja, krzyk, jako przepowiadanie wzywa do nawrócenia, tym samym kierując się bezpośrednio do odbiorców, chce przekonać,

13 J. Wa ro ń s k a, Widowisko i widowiskowość w kulturze ponowoczesnej, w: A. R e g i e w i c z, J. W a r oń s k a, Widowiskowość i audiowizualność w dobie ponowoczesności, Częstochowa 2012, s. 28.

14 R. S c h e c h n e r, Performatyka. Wstęp, tłum. T. K u b i k ow s k i, Wrocław 2006, s. 61-63. 


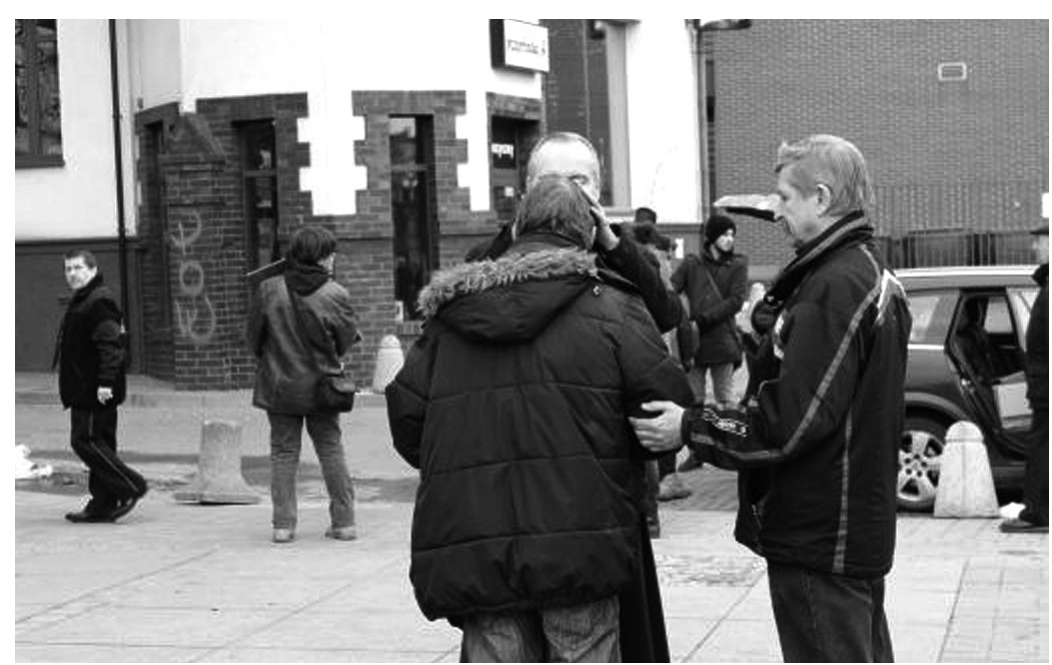

Fot. 5

wykazać konieczność odpowiedzi na to słowo. W tym kontekście można rozumieć kolejną z funkcji, która ma celu zmianę tożsamości. Wezwanie do nawrócenia pociąga za sobą radykalną zmianę życia, chęć odwrócenia się od grzechu, z tego wynikają towarzyszące wydarzeniom ewangelizacyjnym spektakularne reakcje słuchających, chęć zmiany dotychczasowego życia ze względu na poczucie bezsensu życia, niepokój, brak radości itd. Podobnie można odczytywać funkcję uzdrawiającą, którą można odczytać przez konkretne fakty osób cierpiących znajdujących dzięki tym wydarzeniom pomoc: alkoholików, bezdomnych, osób które chciały popełnić samobójstwo (fot. 5). Ze względu na zgromadzenie, które ma charakter wspólnoty, uobecnia się w tym miejscu funkcja wspólnotowa, dająca poczucie jedności, miłości, wzajemnego podtrzymywania. Trudno wyobrazić sobie wydarzenie ewangeliczne bez tego właśnie zaplecza, które nie tyle ma stanowić siłę o charakterze masy, ile pewnego rodzaju wsparcie modlitewne. Pozostałe funkcje są w pewien sposób konsekwencją realizacji ulicznej ewangelizacji. Samo usytuowanie w przestrzeni świeckiej znaków liturgicznych oraz prowadzenie liturgii wraz 
$\mathrm{z}$ tańcem i śpiewami proponuje udział w doświadczeniu nie tylko emocjonalnym, egzystencjalnym, etycznym, ale także estetycznym. To, co jest prezentowane, jest zazwyczaj piękne, w tym znaczeniu, o jakim pisał Fiodor Dostojewski („Piękno zbawi świat”). Z drugiej strony, żywiołowo i dynamizm towarzyszący przepowiadaniu kerygmatu, związany z pieśniami i tańcami, może być postrzegany jako element zabawy. Zdarza się, że jako pierwsi do tego wydarzenia dołączają osoby pijane, które chcą tańczyć wraz ze wszystkimi, lub postrzegają kantorów śpiewających psalmy jako rodzaj karaoke, cierpliwie czekając, aż zacznie się śpiewać i grać coś bardziej znanego i przebojowego.

Analiza tychże funkcji pokazuje, że każdy performance, nawet ten, które intencje mają swoje źródła w transcendencji, jest silnie zrytualizowany. Performance są bowiem zachowanymi zachowaniami, odtworzonymi zachowaniami, działaniami przećwiczonymi i spełnionymi, które wpierw opanowano i wypróbowano. Marvin Carlson dodaje, że performance to wszelka ludzka aktywność (powtarzalne i usankcjonowane społecznie zachowania) wykonywana świadomie. ${ }^{15}$ Wymieniając osiem rodzajów takich performace'ów, wylicza także święte rytuały, które można identyfikować z uliczną ewangelizacją. Wydarzenie to z jednej strony można opisywać w kategorii powtarzalności, wyrażanej przez schemat spotkania, włączenie liturgii, która uzewnętrznia się przez rytuał, a z drugiej postrzegać jako wyraz jedyności i niepowtarzalności ze względu na kontekst odbioru czy niezliczone sposoby organizacji. Przy każdym spotkaniu ulicznym zmienia się skład osobowy: zarówno mówiących, dających świadectwa, katechistów, jak i publiczności, zdecydowanie przypadkowej, przechodzącej, podobnie zmienia się tematyka: inna treść katechezy, inne świadectwa, inne słowo, otwierane $a$ caso.

15 M. C a r s l o n, Performance: A Critical Instroduction, cyt. za: R. S c h e c h n e r, Performatyka, s. 47. 


\section{„Jeszcze chwila, a nie będziecie Mnie widzieć, i znowu chwila, a ujrzycie Mnie" (J 16,16)}

Owa incydentalność wydarzenia, by nie powiedzieć przypadkowość: doboru świadectw, katechistów głoszących kerygmat - zawsze to samo, ale nigdy tak samo - z różnym rozłożeniem akcentów w zależności od osobowości mówiącego, osób słuchających włączonych nagle w wydarzenie, czasem zupełnie nieświadomie, pozwala na zestawić ewangelizacje uliczna z ze specyficznym rodzajem performace'u, jakim jest flash mob. Określenie, którym przyjęło się nazywać sztuczny tłum ludzi (dosł. „błyskawiczny tłum”) gromadzących się niespodziewanie w miejscu publicznym w celu przeprowadzenia krótkotrwałego zdarzenia, zazwyczaj zaskakującego dla przypadkowych świadków, ${ }^{16}$ może jest pewnym nadużyciem w stosunku do opisywanej ewangelizacji, ale pozwala na wyzyskanie jeszcze innych właściwości wydarzenia. Po pierwsze trzeba podkreślić, że przestrzenią właściwą realizacji flash mobów jest miasto, a szczególnie przestrzenie ulokowane centralnie, które w życiu codziennym pełnią ważne funkcje administracyjne, ekonomiczne, komunikacyjne itp. Po drugie najważniejszą ideą jest zabawa, której rozumienie sprowadza się do rozbicia przyzwyczajenia zachowań związanych z danym miejscem. Dlatego też flash mob opiera się na spontaniczności działania zebranej w tym samym miejscu grupy osób nieznających się, ale zwołanych dzięki mediom społecznościowym.

Opisywane tu wydarzenie ewangelizacyjne nosi znamiona flash $m o b u$, czy to ze względu na spontaniczy charakter katechezy (nigdy nie wiadomo, w jakim kierunku się potoczy ze względu na odpowiedzi słuchających, zawiera pewną dozę dowolności), czy żywiołowość tańca lub otwartość na odbiorców włączających się w przebieg. Jak już wspomniano, ewangelizacja uliczna nosi znamiona zabawy, czy to ze względu na wyrażanie emocji: radość, pokój, jedność, czy też ze względu na charakter poszczególnych elementów tejże ewangelizacji:

16 Definicję podaję za: http://www.oxforddictionaries.com/definition/english/ flash+mob\#m_en_gb0972977 (dostęp: 12 XII 2015). 
gra na instrumentach, śpiewy, taniec. Wreszcie, jest to także wydarzenie niespodziewane dla przechodniów i zaskakujące - w niedzielne popołudnie idąc na zakupy spotykają Chrystusa. ${ }^{17}$

$\mathrm{Na}$ inne cechy flash mobu zwraca uwagę Allan Karpow, który dostrzega w nim znamiona happeningu. Niektóre właściwości, wyliczone przez Karpowa, warto przywołać. ${ }^{18}$ Po pierwsze, linia między sztuką a życiem jest płynna, a nawet niezauważalna. $\mathrm{Na}$ podobnym założeniu wspiera się ewangelizacja uliczna, która ma na celu zatarcie sztucznej granicy między życiem a doświadczeniem świętości. Już samo wyznaczenie ewangelizacji w miejscach publicznych jest przełamaniem takiego rozgraniczenia, wynikającego z religijności naturalnej: przestrzeń świecka i miejsce święte. Także głoszenie kerygmatu zawsze odbywa się w odniesieniu się do tego, co tu i teraz w wymiarze egzystencjalnym - do życia codziennego. Po drugie, happeningi (a co za tym idzie flash moby) czerpią temat, materiał i działania zewsząd, przede wszystkim z życia codziennego. Ta właściwość także niezwykle trafnie oddaje istotę ewangelizacji ulicznej, która chce sytuować się zawsze blisko życia codziennego, dlatego lokalizacje są blisko szlaków komunikacyjnych, przestrzeni handlowych, rozrywki. Głoszone świadectwa dodatkowo podkreślają ten aspekt autentyczności egzystencji, wszak w kerygmacie nie chodzi o teologię, ale przepowiadanie życia, osadzonego w głębokim doświadczeniu Boga. Po trzecie, zauważa Karpow, tego typu przedsięwzięcia odbywają się w kilku różnych miejscach rozrzuconych, co świetnie realizuje idea ewangelizacji na „100 placach”, zmienianych rokrocznie, tak by docierać z Dobrą Nowiną w różne miejsca. Po czwarte czas takich wydarzeń nie jest ustalony, jest zmienny i nieciągły, podobnie jak w „głoszeniu na placach”, gdzie czas określany jest liturgią, ale zależy w dużej mierze od przebiegu, słuchających i waha się granicach jednej godziny do dwóch godzin. Po piąte,

17 M. F i u t a k, Czego się spodziewałeś, idąc do sklepu? http://gliwice.gosc.pl/ doc/2441529.Czego-sie-spodziewales-idac-do-sklepu (dostęp: 19 IV 2015).

18 A. K a r p ow, Assemblage, Environment and Happenings, cyt. za: R. S c h e c h n e r, Performatyka, s. 44-45. 
wydarzenia happeningowe, podobnie jak ewangelizacje eliminują publiczność. Każdy obecny jest uczestnikiem a nie obserwatorem, odbiorca kerygmatu jest częścią zgromadzenia, nawet jeśli znalazł się tam przypadkowo.

Zestawienie ewangelizacji z flash mobem jako specyficznym happeningiem nie ma na celu wykazania ich ścisłej przekładalności, bowiem ze względu na stosunek do celowości obu zjawisk już takie być nie może, ale pomaga zwrócić uwagę na dynamizm, spontaniczność i niezwykłą żywiołowość tego pierwszego. Jeśli weźmie się pod uwagę dość stereotypowe postrzeganie członków Kościoła katolickiego zarówno ze względu na wiek, jak i prezentowany światopogląd, to prezentowane zachowanie może budzić zdumienie.

\section{„Nie głosimy bowiem siebie samych...” $(2 \operatorname{Kor} 4,5 \mathrm{a})$}

Przedstawione powyżej metafory teatralne miały na celu pomóc rozumieć zjawisko, które jest obecne od kilku lat w przestrzeni miejskiej. Wydaje się, że przyjęty za antropologią język opisu wydaje się z jednej strony jedyny i właściwy, dający pewne narzędzia analizy tego typu przedsięwzięć, z drugiej zaś jawi się jako niewystarczający, bowiem pomija tak ważny aspekt w działaniu jak kategoria Ducha. Wystarczy dokonać krótkiego wywiadu osób uczestniczących w tego typu wydarzeniach, aby przekonać się, że naprawdę niewielu wśród nich ludzi przebojowych, a tym bardziej „lwów parkietu” czy „zwierząt scenicznych”. Co zatem powoduje, że pojawiają się oni na scenie tego wydarzenia?

Kluczem wydaje się właśnie owo pojęcie „wydarzenie”, które należy rozumieć w takim samym sensie, w jakim chrześcijaństwo jest wydarzeniem. Być może w potocznym myśleniu chrześcijaństwo postrzegane jest jako religia, czyli system praktyk, obrzędów i rytuałów, mający odpowiadać zaspokojeniu duchowej potrzeby człowieku kontaktu z czymś nadprzyrodzonym; albo jako system filozoficzno-etyczny, porządkujący świat i wyznaczający w nim miejsce człowieka, ale to wszystko jest jedynie nadbudową nad wydarzeniem, jaką jest Dobra Nowina wyrażona w kerygmacie. W kluczu 


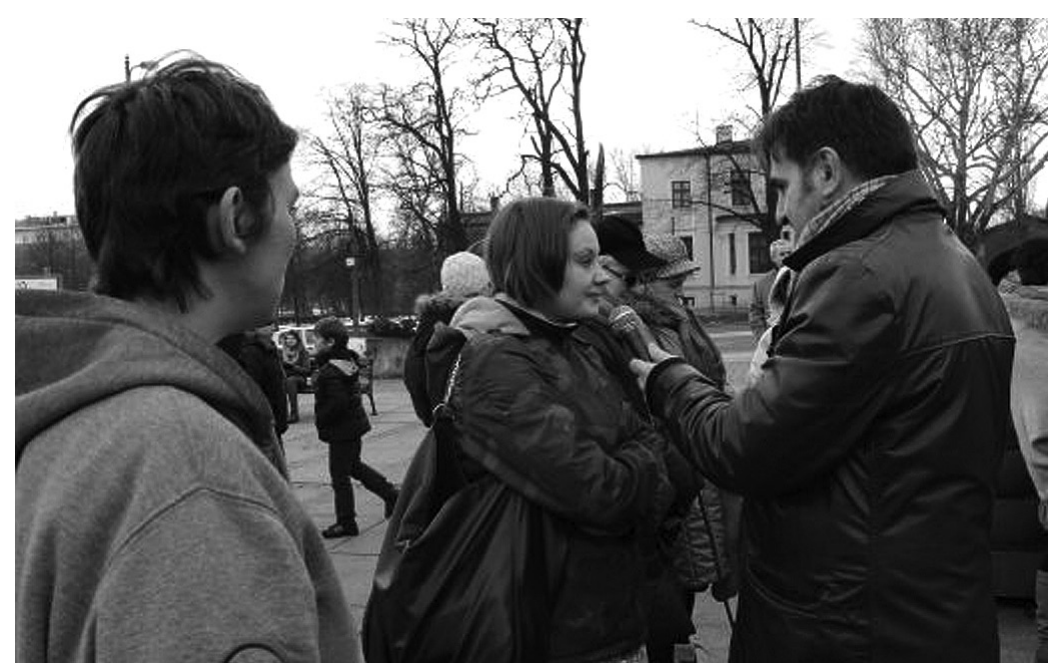

Fot. 6

kerygmatycznym można w taki sam sposób postrzegać zamieszanie uliczne, które przychodzi obwieścić uczestnikowi tej ewangelizacji prawdę o nim samym, a przez to uwolnić go od projekcji, konstrukcji ideologicznych, w które sam siebie wyposażył czy sądów, które posiadał, a które zniekształcały mu obraz rzeczywistości.

Owa wydarzeniowość koresponduje $\mathrm{z}$ heideggerowską koncepcją „wydarzenia”, które prowadzi do stopienia się horyzontu egzystencjalnego ,ja”, granicy ludzkiego Dasein z tym, co stanowi horyzont świata. Heideggerowskie ,wydarzenie się" - w tym przypadku dokonanie się ewangelizacji ulicznej, odwołuje do co najmniej dwóch znaczeń. Pierwsze to „zdarzenie” rozumiane jako historyczny moment dokonania się jakiegoś faktu, zadziania się. Każda z ewangelizacji jest faktem ulicznym, dzieje się w konkretnym czasie i przestrzeni, odbija na uczestniczących, nawet jeśli jest to tylko kontakt chwilowy, przelotny. Drugie to „zderzenie”, które konotuje pewien dramatyzm, napięcie, konflikt stron, tak charakterystyczne dla tych wszystkich spotkań Chrystusa z grzesznikami: ślepcem, Mateuszem celnikiem, trędowatym. Chrystus wychodzi w przestrzeń publiczną, do świata pogan, celników, złodziei i prostytutek. Pojawia się wówczas 
nierozerwalna więź między rzeczywistością a egzystencją (tym, który jej doświadcza), polegająca na wzajemnym oddziaływaniu (zdj. 3). W zderzeniu i zdarzeniu zarówno rzeczywistość jak i uczestnik ją przeżywający ulegają przemianie, zatem każdorazowy udział w ulicznej ewangelizacji, wysłuchanie kerygmatu, zinterpretowaniu go w kluczu egzystencjalnym, do czego ten zawsze zachęca, jest wydarzeniem, mającym realny wpływ na życie.

Adam REGIEWICZ

Slowa kluczowe: kerygmat; ewangelizacja; nie-miejsce; performans; flash mob; widowisko; wydarzenie

Keywords: kerygma; evangelisation; no-place; performance; flash mob; theatre act; event

\section{Kerygma in the City. A Piece of Religious Performance or a Heidegger-like Event? \\ Summary}

For the past few years, on Sundays during the Easter period, groups of Catholics fill city squares (parks, shopping centres and the like) and celebrate the liturgy giving a testimony to Christian life. Very often these places are crossroads of trade, leisure, entertainment and commute trails, hence the celebrations raise actual bewilderment in busy passers-by. Suddenly, by imposing sacral references on the spaces of the profanum, they become symbolic places, the embodiment of a living Church on the move. The article attempts to read these specific meetings in the context of cultural phenomena: a theatre play, a live performance act, flash mobs, and others. The article also contemplates the construction of meaning of such space interpreted anew through the prism of these forms of evangelisation. 